\title{
Contributions of Indigenous Americans to Horticulture: Introduction to the Workshop
}

\author{
Jules Janick ${ }^{1}$ \\ Department of Horticulture and Landscape Architecture, Purdue University, West Lafayette, IN 47907
}

The enormous contribution of Native Americans to world agriculture is an often ignored part of the history of horticulture and agriculture. The first encounter of the socalled "discovery" led to the false conclusion that the civilizations encountered were based on savages and backward peoples, when in reality the New World civilizations were highly developed with massive cities, a tremendous culture, highly developed art and theology, magnificent temples and markets, a written record, and a highly developed agriculture. Some idea of the agriculture at the time of the European encounter with the New World can be gleaned from the artistic record captured by contemporary artists (Fig. 1). Indeed, most of the crop plants that now contribute to world agriculture were in fact domesticated by the indigenous peoples of the Americas. The crops now contribute annually much more value that all the gold stolen and melted down by the conquistadores, and this bounty can be considered the magnificent contribution of the indigenous cultures of the Native American people to humanity.

This workshop, entitled $A$ Survey on the Contribution of Indigenous Americans to Horticulture, is a continuation of a previous one entitled Our Horticultural Heritage from the Americas, also sponsored by the History of Horticulture Working Group, that took place in Salt Lake City, UT, at the 94th Annual Conference of the American Society for Horticultural Science (ASHS) in 1999. That workshop, after an introduction by Chad E. Finn (1999), contained papers on chiles by Paul W. Bosland (1999); vegetable uses of maize by W.F. Tracy (1999); the chiloensis strawberry by J.F. Hancock, A. Lavin, and J.B. Remales (1999); and potato diffusion by Charles R. Brown (1999). The present workshop contains papers developed from three presentations at the 108th Annual Conference of ASHS in Miami, FL: "Development of New World Crops by Indigenous Americans" (Jules Janick), "Manna in Winter: Indigenous Americans, Huckleberries, and Blueberries" (Kim E. Hummer), and "The Chilean Strawberry (Fragaria chiloensis):

Received for publication 25 Jan. 2013. Accepted for publication $21 \mathrm{Feb} .2013$.

This paper was part of the workshop "A Survey on the Contribution of Indigenous People of North America to Horticulture" held 1 Aug. 2012 at the ASHS Conference, Miami, FL, and sponsored by the History of Horticultural Science Working Group (HIST).

${ }^{1}$ To whom reprint requests should be addressed; e-mailjanick@purdue.edu.

A

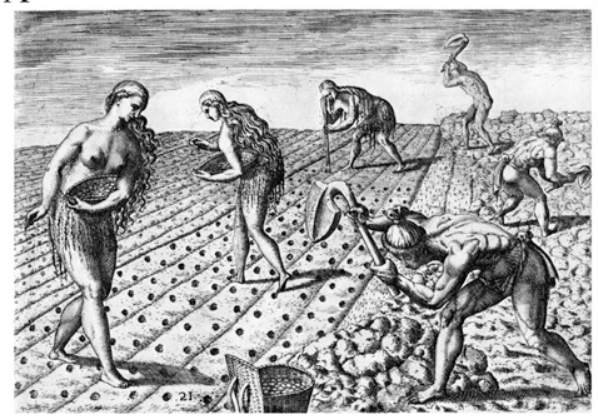

B

$\mathrm{C}$

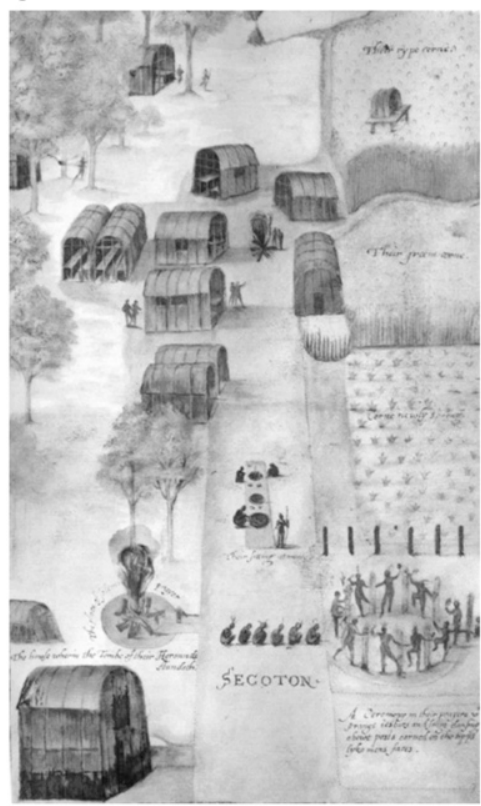

$\mathrm{D}$
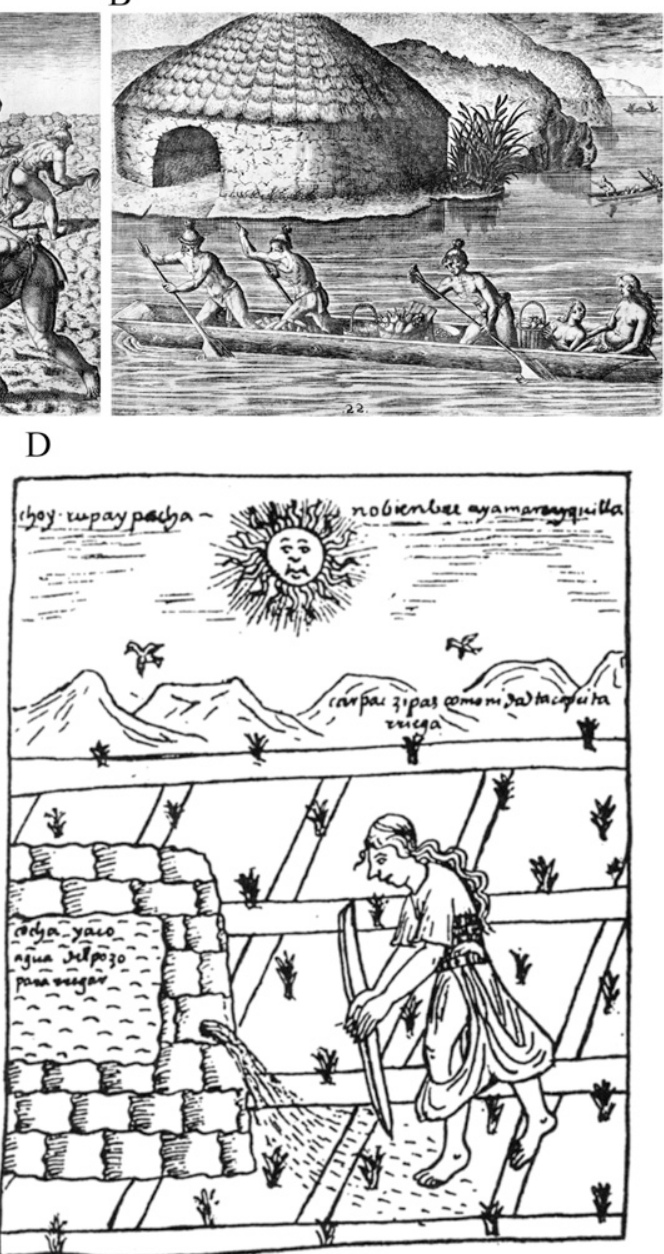

Fig. 1. Contemporary illustrations of indigenous agriculture in the New World: (A) tilling of the soil by men and planting by women in French settlements of Florida approximately 1562-64, from an etching by Theodore de Bry based on lost drawings by Jacques Le Moyne de Morgues; (B) storing of crops in the public granary (source: Lorant, 1946); (C) town of Secoa in Virginia (now North Carolina) near Roanoke showing maize cultivation by John White, 1585 (source: Sloan, 2007); (D) irrigation from calendar of Inca agriculture, First New Chronicle and Good Government (1615) by Incan author Felipe Guaman Poma de Ayala (source: Leonard, 1973).

Over 1000 Years of Domestication" (Chad E. Finn, Jorge B. Retamales, Gustavo A. Lobos, and James F. Hancock).

\section{Literature Cited}

Bosland, P.W. 1999. Chiles: A gift from a fiery god. HortScience 34:809-811.

Brown, C.R. 1999. A Native American technology transfer: The diffusion of potato. HortScience $34: 817-821$.

Finn, C. 1999. Our horticultural heritage from the Americas: Introduction to the workshop. HortScience 34:808-809.
Hancock, J.F., A. Lavín, and J.B. Retamales 1999. Our southern strawberry heritage: Fragaria chiloensis of Chile. HortScience 34: 814-816.

Leonard, J.N. 1973. The first farmers. Time Life Books, New York, NY

Lorant, S. 1946. The New World: The first pictures of America. Duell, Sloan and Pearce, New York, NY.

Sloan, K. 2007. A new world: England's first view of America. University of North Carolina Press, Chapel Hill, NC.

Tracy, W.F. 1999. Vegetable uses of maize (corn) in pre-Columbian America. HortScience 34: 812-813. 